\title{
THE EFFECT OF BENZENE ON THE PRODUCTION OF ANTIBODIES *
}

\author{
LUDVIG HEKTOEN \\ From the Memorial Institute for Infectious Diseases, Chicago
}

Selling ${ }^{1}$ found that in rabbits benzene in suitable doses causes profound destruction in the hemopoietic structures, especially of the marrow, followed when recovery takes place by prompt regeneration, which is complete in from 10 to 20 days. During the height of this effect there develops a marked leukopenia, involving the granular cells relatively more than the lymphocytes. Fatty changes may develop in the kidneys and the liver, and hemorrhages in the lungs and pleura, the stomach, etc. Some reduction of red corpuscles results, embryonal red cells may appear in the blood, and the blood platelets may be reduced also, ${ }^{2}$ marrow giant cells being destroyed. ${ }^{3}$ In view of this more or less selective action of benzene on tissues and cells that are concerned in the production of antibodies and in the defense against infection, it lies near at hand to investigate the course of infection and the production of antibodies in animals under the influence of benzene.

Winternitz and Hirschfelder ${ }^{4}$ found that rabbits in which leukopenia had been produced by means of benzene were little resistant to pneumonia from intratracheal insufflation of pnetumococci, there being only very few letkocytes in the exudate. Kline and Winternitz $z^{\mathrm{b}}$ published further studies on the importance of the leukocytes in the reaction against pneumonia as observable in benzenized rabbits, but they did not study directly the influence of benzene on the production of pneumococcal antibodies.

White and Gammon inoculated rabbits with tubercle bacilli and then gave benzene by way of inhalation. They found that rabbits so treated were less resistant to tuberculosis than rabbits which had not received benzene, but they offered no basis for any explanation of this effect.

In a study of the inflammatory reactions in the ears of rabbits with marked benzene leukopenia, Camp and Baumgartner ${ }^{2}$ noted that there apparently was no restraint on the entrance and growth of bacteria in such animals.

* Received for publication January 7, 1916.

1 Ziegler's Beiträge, 1911, 51, p. 567.

2 Duke: Arch. Int. Med., 1913, 11, p. 100. Hurwitz and Drinker: Jour. Exper. Med., 1915, 21, p. 401 . p. 961 .

${ }^{3}$ Duke: Arch. Int. Med., 1913, 11, p. 100. E. Frank: Berl. klin. Wchnschr., 1915, 52,

4 Jour. Exper. Med, 1913, 17, p. 657.

5 Ibid., 1914, 18, p. 50; 1915, 21, p. 320.

- Tr. Assn. Am. Phys., 1914, 19, p. 332.

? Jour. Exper. Med., 1915, 22, p. 174. 
Schiff $^{8}$ found that in guinea-pigs small doses of benzene-0.01 c.c.-intraperitoneally injected before the injection of antigen increased the reactivity to the second dose of antigen, whereas larger doses of benzene- 0.03 c.c.-decreased the reactivity. Schiff mentioned several explanations but favored the view that the effect most likely is due to the action of benzene on the tissues which produce antibodies.

Rusk was the first to publish results of direct observations on the effect of benzene on antibody-production. He recorded that in rabbits the injection of benzene in doses of 1 c.c. for each kilo of weight, either before or at the same time as the antigen, reduced greatly the formation of lysin for sheep corpuscles and of precipitin for horse serum.

Simonds and Jones ${ }^{10}$ found that in rabbits injected with benzene in doses of about 1 c.c. per kilo of body weight the production of lysin for dog corpuscles and of agglutinin and opsonin for typhoid bacilli was reduced, the reduction being most marked in the case of lysin and least marked in the case of opsonin. In their work, with occasional exceptions, benzene reduced the number of leukocytes in the blood, especially the polymorphonuclears, and sooner or later evidence of damage to the erythroblastic centers appeared in the form of stippled and nucleated red cells, but in both these effects there were observed sharp individual variations.

In connection with other experiments I have been making observations for some time on the action of benzene and certain related substances on the production of antibodies. ${ }^{11}$ It was thought that substances acting so directly on blood-making structures would affect the output of antibodies, in the elaboration of which these structures appear to take the leading part.

For the study of this action, benzene in an equal quantity of olive oil, was injected subcutaneously into rabbits, which had already received, or subsequently were to receive, 30 c.c. of sheep blood intraperitoneally. Quantitative determinations were then made of the newly formed lysin and precipitin. Sheep blood in the quantity mentioned was selected for antigen because I knew from other work that usually it calls forth in otherwise normal rabbits the production of considerable, tho somewhat variable, quantities of lysin for sheep corpuscles and of precipitin for the proteins in sheep blood. Undoubtedly the injection of a considerably smaller quantity of sheep blood would have served the purpose. In order to guard against mistakes of interpretation on account of inherent variation in response to the antigen, each experiment included several animals as nearly as possible of the same age and weight, and the estimations of the antibodies studied extended over the entire period covered by the antibody curve.

s Ztschr. f. Immunitätsf., 1914, 23, p. 61 .

a Univ. Calif. Publ, in Pathol., 1914, 2, p. 139.

10 Jour. Med. Research, 1915, 33, p. 197.

11 A brief report is published in Tr. Chicago Path. Soc., 1915, 9, p. 308. 
The preparation of benzene used in all the experiments was "Benzene Merck. Highest chemical purity-crystallizable."

The details of the following experiments will serve to illustrate the methods of procedure and the principal results.

In the tables and curves the figures referring to "Lysin" represent the highest dilution of the rabbit serum in question in which distinct lysis of sheep corpuscles was produced. The tubes were incubated for 2 hours and then placed in the ice-box until the next morning. In each test the total quantity of the mixtures was 0.6 c.c., of which 0.2 c.c. was $5 \%$ suspension of sheep blood; 0.006 c.c., guinea-pig serum as complement; and the rest, rabbit serum and salt

TABLE 1

The Effect on Lysin and Precipitin in Rabetts, of 8 Consecutive Daily Injectrons of 1 c.c. Benzene, Beginning on the 4th Day after Injection of Shezp Blood

\begin{tabular}{|c|c|c|c|c|c|c|c|c|}
\hline \multirow{2}{*}{$\begin{array}{c}\text { Days After } \\
\text { Injection } \\
\text { of Sheep } \\
\text { Blood }\end{array}$} & \multicolumn{2}{|c|}{ Rabbit 1} & \multicolumn{2}{|c|}{ Rabbit 2} & \multicolumn{2}{|c|}{ Rabbit 3} & \multicolumn{2}{|c|}{ Control } \\
\hline & Lysin & Precipitin & Lysin & Precipitin & Lysin & Precipitin & Lysin & Precipitin \\
\hline $\begin{array}{r}2 \\
4 \\
6 \\
8 \\
9 \\
11 \\
12 \\
13 \\
15 \\
16 \\
17 \\
20 \\
23 \\
28 \\
36 \\
42 \\
49 \\
58\end{array}$ & $\begin{array}{r}384 \\
3072 \\
12288 \\
12288 \\
6144 \\
6144 \\
1536 \\
1536 \\
3072 \\
3072 \\
3072 \\
1536 \\
768 \\
768 \\
768 \\
768 \\
768 \\
48\end{array}$ & $\begin{array}{r}0 \\
0 \\
200 \\
800 \\
200 \\
200 \\
100 \\
50 \\
0 \\
0 \\
\ldots \ldots \\
\ldots \ldots \\
\ldots \ldots \\
\ldots \ldots \\
\ldots \ldots \\
\ldots \ldots \\
\ldots \ldots\end{array}$ & $\begin{array}{r}384 \\
3072 \\
6144 \\
6144 \\
6144 \\
12288 \\
768 \\
1536 \\
3072 \\
3072 \\
3072 \\
1536 \\
768 \\
768 \\
384 \\
384 \\
384 \\
48\end{array}$ & $\begin{array}{r}0 \\
0 \\
0 \\
10 \\
400 \\
800 \\
200 \\
200 \\
100 \\
50 \\
0 \\
\ldots \ldots \\
\ldots \ldots \\
\ldots \ldots \\
\cdots \ldots \\
\ldots \ldots \\
\ldots \ldots \\
\ldots \ldots \\
\ldots \ldots\end{array}$ & $\begin{array}{r}384 \\
192 \\
192 \\
768 \\
1586 \\
3072 \\
384 \\
192 \\
\\
\ldots \ldots \\
\ldots \ldots \\
\ldots \ldots \\
\ldots \ldots \\
\ldots \ldots \\
\ldots \ldots \\
\ldots \ldots \\
\ldots \ldots \\
\ldots . \\
\ldots\end{array}$ & 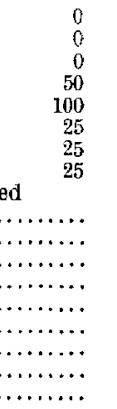 & $\begin{array}{r}768 \\
768 \\
6144 \\
6144 \\
6144 \\
12288 \\
12288 \\
6144 \\
3072 \\
3072 \\
3072 \\
3072 \\
3072 \\
3072 \\
3072 \\
1536 \\
1536 \\
96\end{array}$ & $\begin{array}{r}0 \\
0 \\
50 \\
800 \\
1600 \\
3200 \\
6400 \\
12800 \\
12800 \\
12800 \\
12800 \\
12800 \\
12800 \\
12800 \\
3200 \\
1600 \\
800 \\
200\end{array}$ \\
\hline
\end{tabular}

The figures under "Lysin" give the highest dilution in which distinct lysis of sheep blood was produced.

The figures under "Precipitin" give the highest dilution of water-laked sheep blood with restored salt content in contact with which the rabbit serum formed a definite preeipitate.

solution. Inasmuch as the estimations of $1 y \sin$ were made at frequent intervals during the course of an experiment, and not all at one time, the figures can not be regarded otherwise than as only approximately correct with respect to the concentration of the lysin in the rabbit serum at different bleedings because of the undoubted variations in the activity of the guinea-pig serum used as complement and in the resistance of the sheep corpuscles employed in the different sets of tests. The results are believed to be accurate enough, however, to answer the requirements in this case.

The figures in the tables and curves referring to "Precipitin" give the highest dilution of water-laked sheep blood with restored salt content in contact with which-"ring" or "zonal" method-the serum of the rabbits formed a definite precipitate after 1 hour at room temperature. As the same sheep blood was used in all the estimations, the figures may be regarded as fairly correct, especially since they practically always were made under almost identical conditions. 
In the first experiment the introduction of benzene was begun 4 days after the injection of sheep blood.

Four rabbits of the same litter, weighing from 1,500 to $1,600 \mathrm{gm}$., were given each 30 c.c. of sheep blood intraperitoneally. Four days later the injection of benzene was commenced in 3 of the animals, the 4th serving as control.

TABLE 2

The Effect on Leukocytes, Lysin, and Precipitin in. Rabits, of 10 to 14 Consecutive Daily Injections of 1 c.c. of Benzene, the First on the Same Day That 30 c.c. of Sheep Blood were In jected

\begin{tabular}{|c|c|c|c|c|c|c|c|c|c|}
\hline \multirow{2}{*}{$\begin{array}{c}\text { Days After } \\
\text { Injection } \\
\text { of Sheep } \\
\text { Blood }\end{array}$} & \multicolumn{3}{|c|}{ Rabbit 1} & \multicolumn{3}{|c|}{ Rabbit 2} & \multicolumn{3}{|c|}{ Rabbit 3} \\
\hline & $\begin{array}{c}\text { Leuko- } \\
\text { cytes }\end{array}$ & Lysin & $\begin{array}{c}\text { Precip- } \\
\text { jtin }\end{array}$ & $\begin{array}{l}\text { Leuko- } \\
\text { cytes }\end{array}$ & Lysin & $\underset{\text { itin }}{\text { Precip- }}$ & $\begin{array}{c}\text { Leuko- } \\
\text { cytes }\end{array}$ & Lysin & $\begin{array}{c}\text { Precip } \\
\text { itin }\end{array}$ \\
\hline 1 & & $\ldots$ & $\ldots$ & & $\therefore \ldots$ & $\cdots$ & & $\ldots$ & .. \\
\hline 2 & 4500 & $\ldots$ & $\ldots$ & 5000 & $\ldots$ & $\ldots$ & 3000 & $\ldots$ & $\ldots$ \\
\hline 3 & 5000 & & $\ldots$ & 4500 & . & $\ldots$ & 2800 & & $\ldots$ \\
\hline 4 & 3200 & 1536 & 10 & 4000 & 1586 & 10 & 2400 & 768 & 10 \\
\hline 5 & $\ldots$ & 6144 & 50 & $\ldots$ & 12288 & 50 & $\ldots$ & 1536 & 50 \\
\hline 6 & 3200 & 12288 & 300 & 3800 & 6144 & 100 & 2500 & 1536 & 50 \\
\hline 7 & $\ldots$ & 6144 & 300 & $\ldots$ & & 300 & $\cdots$ & 1536 & 300 \\
\hline 8 & 3300 & 6144 & 300 & 3500 & 12288 & 1200 & 2200 & 1536 & 300 \\
\hline 9 & & 6144 & 300 & ... & 6144 & 1200 & & & 300 \\
\hline 10 & 2800 & & & 4000 & 12288 & & 2200 & 1536 & 300 \\
\hline 11 & $\ldots$ & 6144 & 600 & $\ldots$ & 6144 & 1200 & $\ldots$ & 3072 & 100 \\
\hline 12 & 1800 & 6144 & 300 & $\ldots$ & 6144 & 1200 & 2600 & 1536 & 100 \\
\hline 13 & ... & 6144 & 300 & $\ldots$ & $\ldots$ & 1200 & $\ldots$ & 3072 & 100 \\
\hline 14 & $\cdots$ & 3072 & 300 & $\cdots$ & 12288 & 1200 & $\cdots$ & 3072 & 100 \\
\hline 15 & 2900 & 1536 & 300 & 3900 & 6144 & 1200 & 2800 & 3072 & 100 \\
\hline 16 & $\cdots$ & 1536 & 300 & $\ldots$ & $\cdots$ & 600 & & & \\
\hline 17 & $\ddot{B} \ddot{n}$ & 19.. & $\ddot{i n}$ & … & $\ddot{\text { Gïit }}$ & 600 & $\ddot{2}$ & $\ddot{0} 70^{\circ}$ & $\ddot{i}$ \\
\hline $\begin{array}{l}18 \\
19\end{array}$ & 2000 & 1036 & 100 & 5000 & $\begin{array}{l}0144 \\
6144\end{array}$ & 600 & 3000 & 3072 & 100 \\
\hline 20 & 4800 & 1536 & 100 & $\ddot{5} 400$ & 6144 & 600 & 3200 & $1 \ddot{5} 36$ & 100 \\
\hline 22 & 4200 & 1536 & 100 & 5600 & 6144 & 600 & 3900 & 1536 & 50 \\
\hline 25 & 4000 & 768 & 100 & 5300 & 6144 & 300 & 8000 & 1536 & 50 \\
\hline 30 & 4600 & 768 & 100 & 6000 & 6144 & 200 & $6400^{\circ}$ & 1536 & 50 \\
\hline 35 & 4200 & 768 & 100 & 5600 & 6144 & 100 & 4600 & 1536 & 50 \\
\hline 40 & 4800 & 768 & 100 & 6500 & 3072 & 100 & 2300 & 3072 & 50 \\
\hline 47 & 4425 & 768 & 100 & 5800 & 1536 & 100 & 3800 & 1536 & 50 \\
\hline 54 & $\ldots$ & 768 & 100 & $\ldots$ & 3072 & 200 & $\ldots$ & 768 & 50 . \\
\hline 61 & $\ldots$ & 18 & 50 & $\ldots$ & 1536 & 1600 & $\ldots$ & 384 & 50 \\
\hline 68 & $\ldots$ & $\ldots$ & ... & ... & 768 & 100 & $\ldots$ & 768 & 50 \\
\hline 75 & $\ldots$ & $\cdots$ & $\ldots$ & $\ldots$ & 768 & 100 & $\ldots$ & 768 & 50 \\
\hline 82 & $\ldots$ & $\ldots$ & ... & $\cdots$ & $\cdots$ & 0 & $\cdots$ & 384 & 0 \\
\hline 92 & $\ldots$ & ... & $\cdots$ & $\cdots$ & $\ldots$ & $\cdots$ & $\cdots$ & $\cdots$ & $\cdots$ \\
\hline
\end{tabular}

Rabbits 1, 2, and 3 received 14, and Rabbits 4 and 5, 10 injections of benzene.

The figures under "Lysin" give the highest dilution in which distinet lysis of sheep blood was produced.

Daily injections of 1 c.c. in 1 c.c. of olive oil were given subcutaneously for 8 days. The animals were bled every 2 nd day or so until the 17 th day, and thereafter at longer intervals, the amount of blood withdrawn each time being from 2 to 3 c.c. In the benzene rabbits the leukocytes rapidly fell to 2,000 or less, the number rising after a few days to fall again before coming to rest at about the normal level.

The results as to lysin and precipitin are given in Table 1 . The chief effect of the benzene is seen to be reduction of the precipitin titer. In Rabbit 3, which died 15 days after the injection of sheep 
blood, only a small amount of lysin was produced. The results obtained with the serum of the control in this experiment correspond fairly well with the titer of normal rabbits in general injected with 30 c.c. of sheep blood, the lysin titer being, however, rather lower than usual (see Control, Table 2).

TABLE 2-Continued

The Effect on Leghocytes, Lysin, and Precipitin in Rabeits, of 10 to 14 Consecutive Daily Injections of 1 c.c. of Benzene, the First on the Same Day That 30 c.c. of Sheep Blood were Injected

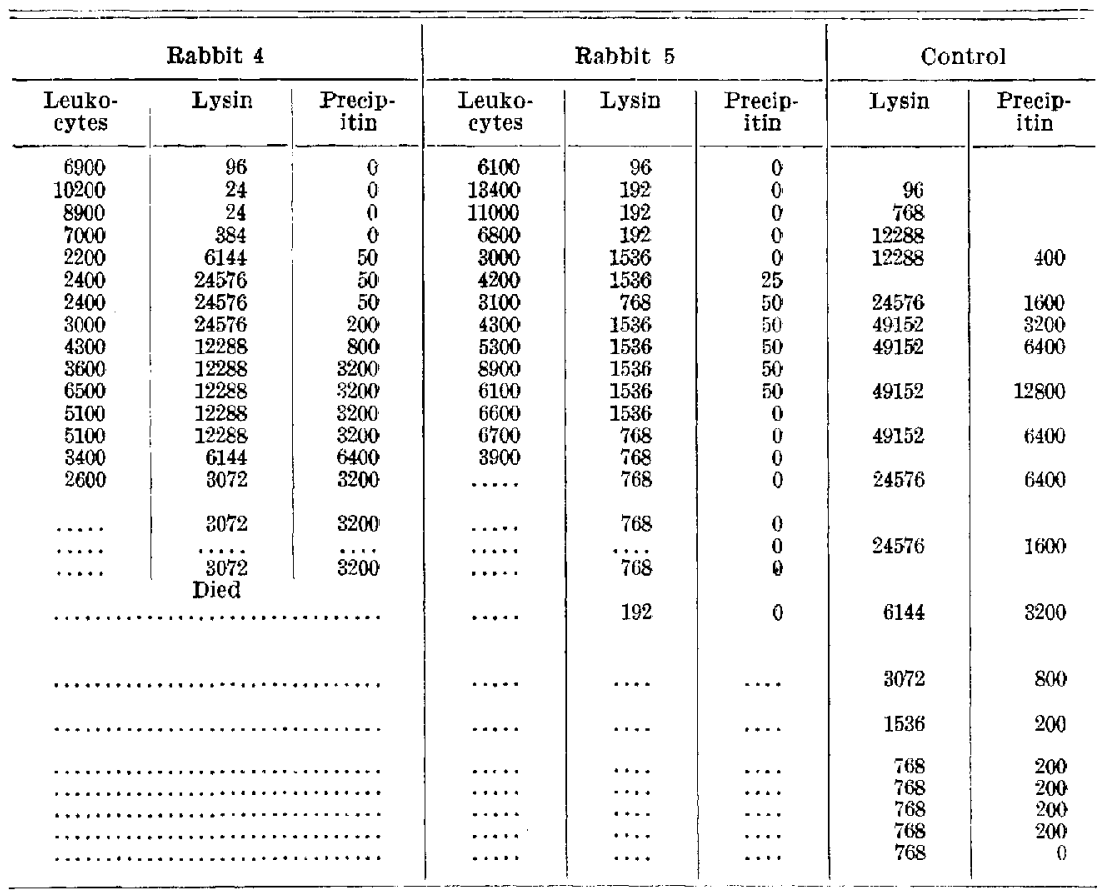

The figures under "Precipitin" give the highest dilution of water-laked sheep blood with restored salt content in contact with which the rabbit serum formed a definite precipitate.

In the next experiment the administration of benzene was commenced on the same day that the sheep blood was injected and then continued daily in some animals for 10 days, in others for 14 (Table 2). Practically the same results were obtained as in the first experiment; namely, marked reduction in the precipitin titer and in some rabbits reduction in lysin also. In Rabbit 4 , which received 1 c.c. of benzene per kilo daily for 14 days, considerable reduction of letkocytes was observed, but in this animal the amounts of lysin and precipitin were not 
much less than in many nonbenzenized rabbits. In Rabbit 5, however, which was treated in the same way, the leukocytes seem to have been reduced less and the lysin and precipitin more, a divergence of results that one might regard as due to a natural variation in the power to produce antibodies.

The following experiment illustrates the result when benzene is injected daily for some days both before and after the injection of sheep blood. The figures of Table 3 appear to show that in rabbits

TABLE 3

The Effect on tie Production of Antibodies of Injections of Benzene (1 t.c. per Kilo) for Some Time Before and After the Injection of the Antigen

\begin{tabular}{|c|c|c|c|c|c|c|c|c|c|c|c|c|}
\hline \multirow{2}{*}{$\begin{array}{c}\text { Days After } \\
\text { Injection } \\
\text { of } \\
\text { Sheep } \\
\text { Blood } \\
\end{array}$} & \multicolumn{3}{|c|}{ Rabbit 1} & \multicolumn{3}{|c|}{ Rabbit 2} & \multicolumn{3}{|c|}{ Rabbit 3} & \multicolumn{3}{|c|}{ Rabbit 4} \\
\hline & $\begin{array}{l}\text { Leu- } \\
\text { ko- } \\
\text { cytes }\end{array}$ & Lysin & $\begin{array}{l}\text { Pre- } \\
\text { clp- } \\
\text { itin }\end{array}$ & $\begin{array}{l}\text { Leu- } \\
\text { ko- } \\
\text { cytes }\end{array}$ & Lysin & $\begin{array}{l}\text { Pre- } \\
\text { cip- } \\
\text { itin }\end{array}$ & $\begin{array}{c}\text { Leu- } \\
\text { ko- } \\
\text { cytes }\end{array}$ & Lysin & $\begin{array}{l}\text { Pre- } \\
\text { cip- } \\
\text { itin }\end{array}$ & $\begin{array}{l}\text { Leu- } \\
\text { ko- } \\
\text { cytes }\end{array}$ & Lysin & $\begin{array}{l}\text { Pre- } \\
\text { cip- } \\
\text { itia }\end{array}$ \\
\hline $\begin{array}{r}1 \\
2 \\
8 \\
4 \\
5 \\
6 \\
7 \\
8 \\
9 \\
10 \\
11 \\
12 \\
14 \\
16 \\
18 \\
21\end{array}$ & $\begin{array}{c}5000 \\
4500 \\
3500 \\
3700 \\
4500 \\
6300 \\
1400 \\
3000 \\
1800 \\
5600 \\
3400 \\
\ldots \ldots \\
5200 \\
4600 \\
3000 \\
\ldots \ldots 00 \\
1000 \\
3400 \\
1600 \\
\dddot{2} 0 \\
9000^{*} \\
8400^{\circ} \\
1800\end{array}$ & \begin{tabular}{r}
$\ldots \ldots$ \\
$\ldots \ldots$ \\
$\ldots \ldots$ \\
$\ldots \ldots$ \\
$\ldots \ldots$ \\
$\ldots \ldots$ \\
$\ldots \ldots$ \\
$\ldots \ldots$ \\
384 \\
384 \\
1536 \\
\hdashline$\ldots$ \\
$\mathbf{1 5 3 6}$ \\
768 \\
\hdashline$\ldots$ \\
1536 \\
\hdashline$\ldots 36$ \\
768 \\
768 \\
768
\end{tabular} & $\begin{array}{r}\ldots \ldots \\
\ldots \ldots \\
\ldots \ldots \\
\ldots \ldots \\
\ldots \ldots \\
\ldots \ldots \\
\ldots \ldots \\
\ldots \ldots \\
\ldots \ldots \\
100 \\
0 \\
50 \\
\ldots \\
50 \\
100 \\
\cdots \\
100 \\
\ldots \ldots \\
0 \\
0 \\
0 \\
0\end{array}$ & $\begin{array}{c}4600 \\
2700 \\
5300 \\
2300 \\
7500 \\
5300 \\
2000 \\
4200 \\
5400 \\
7400 \\
3400 \\
\ldots \ldots \\
4400 \\
4500 \\
3200 \\
\cdots \ldots 00 \\
\mathbf{5 0 0 0} \\
\mathbf{6 0 0 0} \\
7200 \\
3000 \\
\mathbf{3 0 0 0} \\
\mathbf{4 0 0 0} \\
3000\end{array}$ & $\begin{array}{c}\ldots \ldots \\
\ldots \ldots \\
\ldots \ldots \\
\ldots \ldots \\
\ldots \ldots \\
\ldots \ldots \\
\ldots \ldots \\
\ldots \ldots \\
\ldots \ldots \\
192 \\
192 \\
768 \\
\ldots \\
1536 \\
768 \\
\ldots \\
768 \\
\ldots \ldots \\
384 \\
384 \\
384 \\
384\end{array}$ & 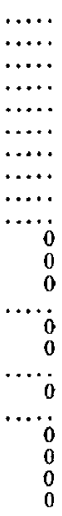 & $\begin{array}{r}5000 \\
5000 \\
6200 \\
5400 \\
6800 \\
6300 \\
6000 \\
8000 \\
4800 \\
10200 \\
8000 \\
\ldots \ldots \\
5400 \\
10000 \\
5000 \\
\ldots \ldots \\
4400 \\
8400 \\
\ldots \ldots \\
\ldots \ldots 0 \\
2600 \\
5000 \\
4100\end{array}$ & $\begin{array}{c}\ldots \ldots \\
\ldots \ldots \\
\ldots \ldots \\
\ldots \ldots \\
\ldots \ldots \\
\ldots \ldots \\
\ldots \ldots \\
\ldots \ldots \\
1536 \\
3072 \\
6144 \\
\ldots \ldots 144 \\
6144 \\
\ldots \ldots 144 \\
\dddot{6} \ldots 79 \\
3072 \\
1536 \\
1536\end{array}$ & $\begin{array}{c}\ldots \ldots \\
\ldots \ldots \\
\ldots \ldots \\
\ldots \ldots \\
\ldots \ldots \\
\ldots \ldots \\
\ldots \ldots \\
\ldots \ldots \\
\ldots \ldots \\
0 \\
0 \\
100 \\
\ldots \ldots 0 \\
600 \\
1600 \\
\ldots \ldots \\
1600 \\
\ldots \ldots \\
1600 \\
800 \\
400 \\
400\end{array}$ & $\begin{array}{c}6100 \\
4500 \\
7200 \\
6800 \\
6600 \\
5100 \\
5600 \\
9600 \\
4600 \\
9400 \\
6800 \\
\ldots \ldots 0 \\
4400 \\
2600 \\
2000 \\
\cdots \\
2600 \\
2400\end{array}$ & \begin{tabular}{c|}
$\ldots \ldots$ \\
$\ldots \ldots$ \\
$\ldots \ldots$ \\
$\ldots \ldots$ \\
$\ldots \ldots$ \\
$\ldots \ldots$ \\
$\ldots \ldots$ \\
$\ldots \ldots$ \\
$\ldots \ldots 36$ \\
3072 \\
6144 \\
$\ldots \ldots$ \\
3072 \\
6144 \\
$\ldots 1$ \\
6144 \\
Died
\end{tabular} & 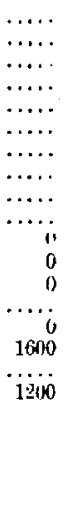 \\
\hline
\end{tabular}

* Suppuration about gangrenous area in skin.

The fgures under "Lysin" give the highest dilution in which distinct Iysis of sheep blood was produced.

The figures under "Precipitin" give the highest dilution of water-laked sheep blood with restored salt content in contact with which the rubbit serum formed a defnite precipitate.

so treated the amount of antibody set free may be very small, even tho the reduction of leukocytes is not extreme. The same general result is illustrated also by the record of 1 member of a group of 6 , the other members of the group dying too early to permit extended observations, the resuis so far as they went, however, having the same bearing.

The rabbit weighed $1,030 \mathrm{gm}$. It was given 1 c.c. of benzene for 8 consecutive days; the leukocytes not falling, it was given 2 c.c. on each of the next 2 days, and for 3 days 3 c.c. each day. Two days later it received intrageritoneally 30 c.c. of sheep blood. The leukocytes remained at about 6,000 
until about 5 days after the last injection of benzene; then their number fell to 3,500 ; subsequently the number remained between 4,000 and 5,000 for about 25 days and then rose to 6,000 or more. The amount of precipitin formed after the injection of sheep blood was insignificant; only on two days, the 6 th and the 15 th, did the titer reach 100 . The amount of lysin produced was also small, the highest titer being 768 on the 20 th day. On the 56 th day after the first injection of sheep blood 30 c.c. of sheep blood were injected again and large amounts of lysin and precipitin were produced with more promptress than in the fresh animal.

TABLE 4

The Effect of Benzene When Injected at the Helght of Antraody Production

\begin{tabular}{|c|c|c|c|c|c|c|c|}
\hline \multirow{2}{*}{$\begin{array}{l}\text { Days After } \\
\text { Injection } \\
\text { of } 30 \text { c.c. } \\
\text { Sheep Blood }\end{array}$} & \multirow{2}{*}{$\begin{array}{l}\text { Injection } \\
\text { of } \\
\text { Benzene, } \\
\text { c.c. }\end{array}$} & \multicolumn{2}{|c|}{ Rabbit 1} & \multicolumn{2}{|c|}{ Rabbit 2} & \multicolumn{2}{|c|}{ Rabbit 3} \\
\hline & & Lysin & $\begin{array}{l}\text { Precip- } \\
\text { itin }\end{array}$ & Lysin & $\begin{array}{l}\text { Precip- } \\
\text { itin }\end{array}$ & Lysin & $\begin{array}{l}\text { Precip- } \\
\text { itin }\end{array}$ \\
\hline $\begin{array}{r}1 \\
2 \\
3 \\
4 \\
5 \\
6 \\
7 \\
8 \\
10 \\
11 \\
12 \\
13 \\
15 \\
17 \\
18 \\
20 \\
22 \\
25 \\
28 \\
32 \\
35 \\
42 \\
50 \\
59 \\
70 \\
77 \\
84 \\
94 \\
103 \\
113 \\
129 \\
145 \\
161 \\
174 \\
186 \\
208 \\
216\end{array}$ & 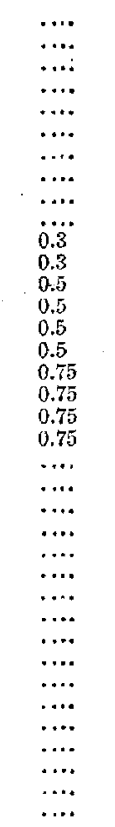 & 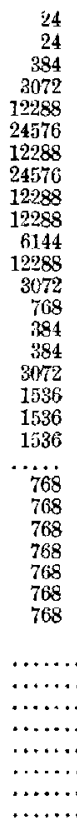 & $\begin{array}{r}\ldots \ldots \\
\ldots \ldots \\
\ldots \ldots \\
\ldots \ldots \\
100 \\
400 \\
600 \\
600 \\
2400 \\
2400 \\
2400 \\
2400 \\
1600 \\
1600 \\
1600 \\
1600 \\
2400 \\
1200 \\
1200 \\
1200 \\
1200 \\
1200 \\
1200 \\
1200 \\
1200 \\
600 \\
300 \\
300 \\
\\
\ldots \ldots \ldots \\
\ldots \ldots \ldots \\
\ldots \ldots \ldots \\
\ldots \ldots \ldots \\
\ldots \ldots \ldots \\
\ldots \ldots \ldots \\
\ldots \ldots \ldots\end{array}$ & $\begin{array}{r}0 \\
0 \\
384 \\
6144 \\
49152 \\
24576 \\
24576 \\
24576 \\
24576 \\
12288 \\
24576 \\
24576 \\
3072 \\
3072 \\
3072 \\
3072 \\
12288 \\
12288 \\
6144 \\
6144 \\
6144 \\
3072 \\
6144 \\
768 \\
768 \\
768 \\
768 \\
768 \\
768 \\
384 \\
384 \\
768 \\
768 \\
792 \\
384 \\
384 \\
384\end{array}$ & $\begin{array}{c}\ldots \ldots \\
\ldots \ldots \\
\ldots \ldots \\
\ldots \ldots \\
50 \\
400 \\
600 \\
600 \\
600 \\
2400 \\
2400 \\
2400 \\
2400 \\
3200 \\
3200 \\
6400 \\
9600 \\
9600 \\
4800 \\
2400 \\
9600 \\
19200 \\
12800 \\
3200 \\
4800 \\
2400 \\
600 ? \\
640 \\
200 \\
1100 \\
800 \\
200 \\
200 \\
100 ? \\
0 \\
0 \\
0\end{array}$ & $\begin{array}{r}0 \\
0 \\
768 \\
6144 \\
12288 \\
24576 \\
24576 \\
24576 \\
24576 \\
24576 \\
12288 \\
12288 \\
1536 \\
1536 \\
768 \\
768 \\
3072 \\
3072 \\
3072 \\
3072 \\
3072 \\
I\end{array}$ & $\begin{array}{c}\ldots . \\
\ldots \\
\ldots \\
\ldots \\
100 \\
400 \\
400 \\
1200 \\
2400 \\
4800 \\
4800 \\
4800 \\
4800 \\
6400 \\
6400 \\
3200 \\
3200 \\
3200 \\
3200 \\
9600 \\
36000 \\
1300\end{array}$ \\
\hline
\end{tabular}

The figures under "Iysin" give the highest dilution in which distinct lysis of sheep blood was produced.

The flgures under "Precipitin" give the highest dilution of water-laked sheep blood with restored salt content in contact with which the rabbit serum formed a definite preeipitate.

The effect of benzene on the production of antibodies when production was at or near the height of the curve, was tested also. Rabbits were injected intraperitoneally with 30 c.c. of sheep blood and on the 12 th day or so injections of benzene were commenced. In the first 
experiment of this kind all the animals died soon after the injections of 1 c.c. per kilo of benzene were started, and on this account in the next experiment (Table 4) the initial quantity injected was reduced to 0.3 c.c. per kilo and then gradually increased as shown in the table. There was no definite decrease in the leukocytes after the injections of benzene. The results indicate some temporary reduction of lysin in the blood but no definite effect on the precipitin. In all the animals the production of lysin and precipitin persisted longer and the precipitin underwent much more fluctuation than is the case under ordinary circumstances. Just before it died, Rabbit 3 of this experiment gave a marked sharp rise in precipitin content.

TABLE 5

Injection of Benzene at the Height of Antibody Production

\begin{tabular}{|c|c|c|c|c|}
\hline $\begin{array}{l}\text { Days } \\
\text { After 2nd } \\
\text { Injection } \\
\text { of } 30 \text { c.c. } \\
\text { Sheep } \\
\text { Blood }\end{array}$ & Injections of Benzene & Lysin & Precipitin & Remarks \\
\hline $\begin{array}{r}3 \\
5 \\
7 \\
8 \\
9 \\
10 \\
11 \\
12 \\
13 \\
14 \\
15 \\
17 \\
19\end{array}$ & 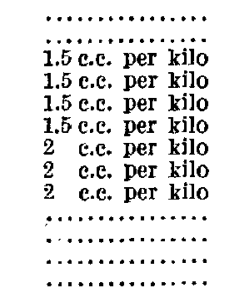 & $\begin{array}{l}12288 \\
49152 \\
49152 \\
49152 \\
12288 \\
\\
12288 \\
24576 \\
12288 \\
\dddot{12288} \\
12288 \\
12288\end{array}$ & $\begin{array}{r}200 \\
800 \\
6400 \\
25600 \\
19200 \\
\\
12800 \\
19600 \\
25600 \\
25600 \\
25600 \\
25600 \\
25600\end{array}$ & No reduction of leukocy tes \\
\hline
\end{tabular}

In several other experiments of the same kind benzene has had a similar effect, even when given in much larger doses. Table 5 gives the results in a rabbit which had received 1.5 c.c., eventually 2 c.c., of benzene per kilo each day for several days during the height of the production of antibodies after a second injection of 30 c.c. of sheep blood. Reference may be made also to the injection of benzene without any recognizable effect in rabbits treated with toluene during the early stages of the production of antibodies for sheep blood. In 2 rabbits, which received 12 consecutive daily injections of toluene, approximately 1 c.c. per kilo, the 1 st on the same day that 30 c.c. of sheep blood were injected, the injection some $21 / 2$ months later of 13 daily doses of 1 to 1.5 c.c. of benzene per kilo had no marked effect on the number of leukocytes, the course of antibodies, or the general health of the animals so far as ascertainable. The details of this experiment will be given later. 
When doses smaller than 1 c.c. per kilo of benzene were given to rabbits injected with 30 c.c. of sheep blood, the reduction in antibodies was less pronounced, and $0.005,0.01$, and 0.025 c.c. per kilo, given daily for several days both before and after the injection of the antigen, appeared to have but little appreciable effect. There were no indications that the smaller doses just mentioned -0.01 c.c. and 0.005 c.c.cause any stimulation of the production of antibodies so as to lead to a greater concentration in the serum than in the control rabbits even tho such doses may induce a moderate degree of leukocytosis. In dogs, however, relatively small doses of benzene appeared to increase the production of antibodies (Table 6). It would be of interest to test more thoroughly the effect of small doses of benzene when given as indicated and also during the height of the antibody curve.

TABLE 6

The Efrect of Benzene in Syalt. Doses on the Blood and un tiek formation of Lysin IN THE DOG

\begin{tabular}{|c|c|c|c|c|}
\hline $\begin{array}{l}\text { Days After } \\
\text { IDjection of } \\
1 \text { c.e. of a } \\
10 \% \text { Suspension } \\
\text { of Goat Blood } \\
\text { per Kilo of } \\
\text { Weight of Dog }\end{array}$ & $\begin{array}{c}\text { Injections } \\
\text { of } 0.2 \text { c.c. of } \\
\text { Benzene } \\
\text { per Kilo of } \\
\text { Weight of Dog }\end{array}$ & $\begin{array}{l}\text { Lysin (The } \\
\text { fgures give } \\
\text { highest active } \\
\text { dilution of } \\
\text { dog serum) }\end{array}$ & Red Corpuscles & Leukocytes \\
\hline $\begin{array}{r}1 \\
2 \\
3 \\
4 \\
5 \\
6 \\
7 \\
8 \\
9 \\
10 \\
11 \\
13 \\
18 \\
23 \\
30\end{array}$ & $\begin{array}{l}+ \\
+ \\
+ \\
+ \\
+ \\
+ \\
+ \\
+\end{array}$ & $\begin{array}{r}24 \\
24 \\
24 \\
48 \\
768 \\
6144 \\
644 \\
24576 \\
98304 \\
98304 \\
49152 \\
49152 \\
49152 \\
49152 \\
24576 \\
24566 \\
12988\end{array}$ & $\begin{array}{l}7896000 \\
7990000 \\
8334000 \\
7560000 \\
6240000 \\
7152000 \\
603400010 \\
6040000 \\
6589000\end{array}$ & $\begin{array}{l}30300 \\
34450 \\
20000 \\
\\
20350 \\
27000 \\
30950 \\
35850 \\
31625 \\
29400\end{array}$ \\
\hline
\end{tabular}

In muking the tests the dog serum was heated to $58 \mathrm{C}$. for 30 minutes: each mixturn measured 0.6 c.c., 0.2 c.c. being a $5 \%$ suspension of goat blood; 0.0125 c.c., guinea-pig serumi as complement; the rest, dog serum and salt solution.

Besides this study on rabbits, I have made a few observations on the action of benzene on the dog and on the white rat.

In dogs the subcutaneous injection of 1 c.c. of benzene for each kilo of weight may cause at first leukocytosis, sometimes as high as 60,000 to 70,000 , reduction of leukocytes taking place only after many injections and the development of fatty changes and hemorrhages. On account of the severe local and general effects no extended experiments 
have been made. Table 6 gives the results of an experiment in which 0.2 c.c. of benzene per kilo of the body weight was injected several times; not only did leukocytosis develop, but the number of red corpuscles remained high and the production of lysin for goat corpuscles reached a very high point. Usually the highest point reached by the lysin after the injection of 1 c.c. of a 10\% suspension of goat blood per kilo of the weight of the dog in otherwise normal animals is from 12,288 to 24,576 .

In the white rat doses larger than 1 c.c. for each kilo of weight were required to depress the number of leukocytes in the blood. The most pronounced results were obtained after from 4 to 5 daily doses of from 0.6 to 0.8 c.c. of benzene with olive oil to make 2 c.c., injected subcutaneously in rats weighing from 130 to $160 \mathrm{gm}$. Usually the leukocytes began to fall after the 2 nd or 3 rd injection, and in a day or two the number might run less than 2,000; a gradual return to normal set in about 3 or 4 days after the injection of benzene was stopped. The injection of sheep blood (10\% suspension) in the dose of 5 c.c. per kilo. of weight at the end of such benzene treatment was followed by a much smaller production of specific lysin than followed in the case of rats injected with sheep blood but not with benzene. It was noted, however, that the lysin titer of the serum of benzenized rats might continue above the normal a little longer than in the untreated rats. The death rate was high in experiments on rats with benzene, even when much smaller doses than those mentioned were given.

In the course of this work many of the observations by Selling and others on the effect of benzene, in doses of 1 c.c. per kilo of weight of rabbit, on the leukocytes in the peripheral blood and on the general condition have been verified. In most cases a few injections given daily caused a distinct leukopenia, affecting the granular cells much more than the lymphocytes, and frequently also some diminution of the number of red corpuscles. In animals with extreme leukopenia the death rate was high, and in the rabbits that died while under the influence of benzene the bone marrow was poor in cells. After the first injections of benzene there sometimes occurred a preliminary leukocytosis of moderate degree. A rise in the number of leukocytes followed by a second fall before return to the normal level, as emphasized by Weiskotten, Schwartz and Steensland, ${ }^{12}$ was observed in a number of animals.

12 Jour. Med. Research, 1915, 33, p. 127. 
In animals with distinct benzene leukopenia there was nearly always a marked reduction in the amount of lysin and precipitin, but the general form of the curves described by these substances in passing into and out of the blood resembled that of the curves in nonbenzenized rabbits, the lysin reaching the high point earlier than the precipitin, but the last phase of the curve-the gradual return to the normal-sometimes persisted longer in the benzenized animals (Charts 1 and 2).

Exceptionally rabbits were encountered in which many consecutive daily injections of 1 c.c. of benzene per kilo appeared to have little or no effect on the number of leukocytes in the peripheral blood. In these animals the relative number of granular leukocytes night be diminished while the relative number of lymphocytes was increased; in some of the resistant rabbits the production of antibodies did not seem affected nearly so much as in leukopenic rabbits.

At the height of antibody-production benzene may have little, if any, effect (Tables 4 and 5) either on antibody concentration in the serum or on the leukocytes. It appears as if rabbits at this time may have an increased resistance to benzene, and it is noteworthy too that in rabbits injected with benzene at this time, the antibodies persist longer and may undergo greater fluctuation in concentration than in rabbits not so treated.

Hamburge ${ }^{13}$ finds that in the test tube small amounts of benzene promote phagocytosis, but in rabbits with benzene leukopenia, no such effect is demonstrable. As benzene leukopenia is established, the leukocytes in the blood may appear more or less injured (as observed by Smith ${ }^{14}$ in the blood of leukemic patients treated with benzene) and their phagocytic activity becomes reduced, the cytophagic index for staphylococcus under the opsonic influence of normal rabbit serum having been found as low as 0.5 to 0.3 with leukocyte counts of about 1,800 . Hence we may conclude that benzene may lower the anti-infectious powers of the body in at least 3 ways : by reduction of antibodies, by reduction of the number of leukocytes, and by reduction of the phagocytic activity of leukocytes. That the unguarded use of benzene in the treatment of leukemia may be associated with danger on account of its lowering the resistance to infection, is hardly to be doubted, especially in view of the course of events in some cases so treated.

The obvious explanation of the depression of antibody-formation under benzene is damage to the marrow and the lymphatic structures.

13 Lancet, 1916, 1, p. 37.

34 Tour. Am. Med. Assn., 1915, 64, p. 1734. 


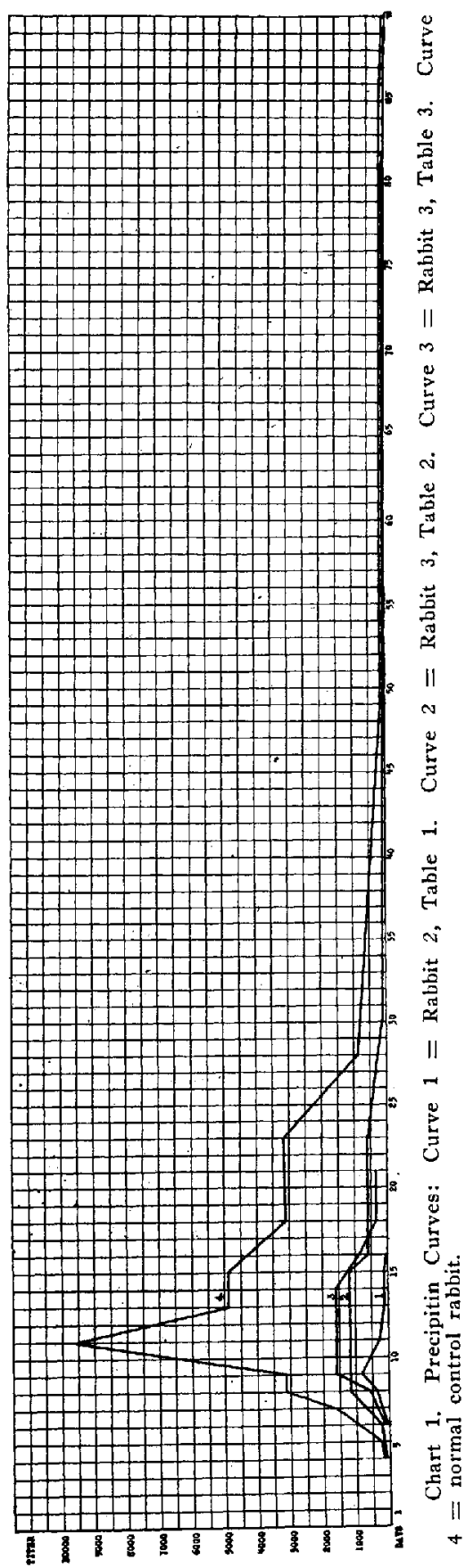


which we have strong reasons to believe are concerned directly with this formation.

Pfeiffer and Marx ${ }^{15}$ and others ${ }^{\text {th }}$ have shown that various antibodies can be demonstrated in the bone marrow, spleen, and lymph glands before they can be demonstrated in the blood; under certain circumstances the removal of the spleen diminishes the amount of antibody produced $;^{17}$ when the blood-making organs are stimulated, as in acute anemia, the production of antibodies is increased; when the blood-making tissues are destroyed, as by Roentgen ray, the production is diminished $;^{18}$ and finally, it has been shown recently by Carrell and Ingebrigtson ${ }^{19}$ and others ${ }^{20}$ that in the presence of antigenic substances, cultures of the spleen and bone marrow outside of the body may manufacture antibodies (lysin, agglutinin, precipitin)..$^{21}$

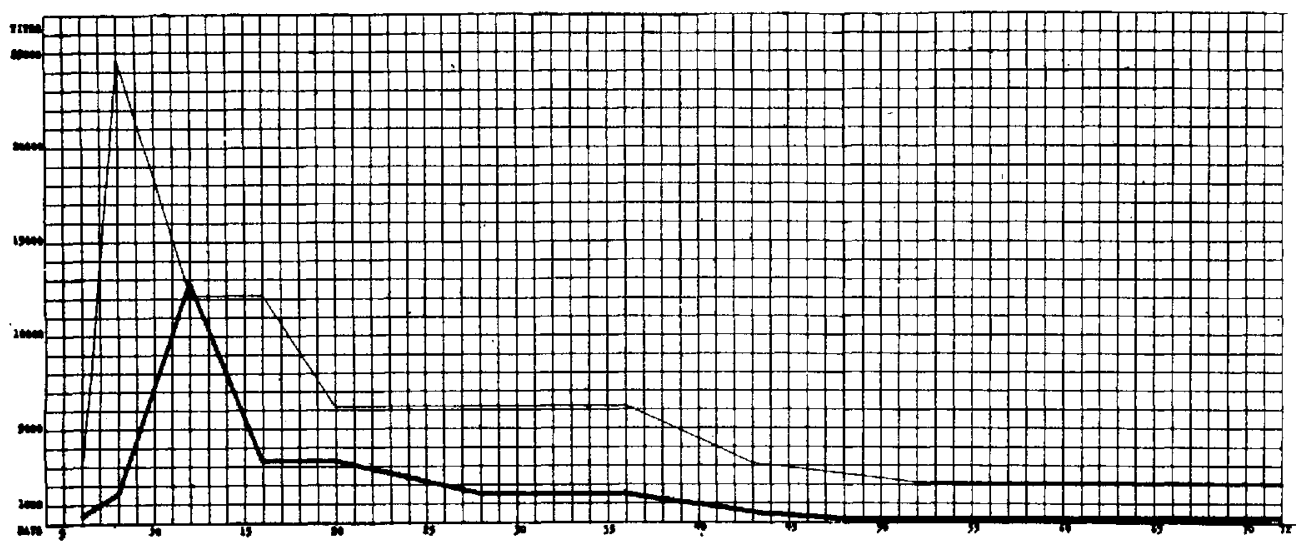

Chart 2. Lysin and Precipitin Curves: Fine line $=$ lysin. Heavy line $=$ precipitin.

Just how benzene interferes with the elaboration of antibodies, whether by direct injury to cells, which seems likely in view of its destructive effects on the tissues concerned, or possibly by modification of enzyme action without necessary injury to cells, are questions that at present seem difficult of solution. That benzene, in spite of its affinity for the nervous tissues according to Joachimoglu, ${ }^{22}$ acts on the

15 Ztschr. f. Hyg. u. Infektionskrankh., 1898, 27, p. 272.

16 Cantacuzene: Ann. de l'Inst. Pasteur, 1902, 16, p. 552; 1908, 22, p. 54. Tsurumi and Kohda: Ztschr. f. Immunitätsf., 1913, 19, p. 519.

17 Deutsch: Ann. de l'Inst. Pasteur, 1899, 13, p. 689.

18 Hektoen: Jour. Infect. Dis., 1915, 17, p. 415. Simonds and Jones: Jour. Med. Research, 1915, 33, p. 183.

10 Jour. Exper. Med., 1912, 15, p. 287.

20 Lüdke: Berl. klin. Wchnschr., 1912, 49, p. 1034. Przygode: Wien. klitl. Wchnschr., 1913,26, p. $841 ; 1914,27$, p. 201.

21 For more complete discussion of the earlier literature see Hektoen, Harvey Society Lectures, 1909.10, p. 177, and Gay and Rusk, Tr. 15th Internat. Cong. on Demography and Hygiene, 1913, 2, p. 378.

"2 Biochem. Ztschr., 1915, 70, p. 93 . 
elements concerned in the elaboration of antibodies and that the leukocytogenic centers are concerned in this elaboration is indicated not only by the reduction of antibodies in benzene leukopenia but also, it seems to me, by the resistance to these effects of benzene at the time when the production of antibodies is at or near its height, and by the leukocytosis and increased lysin-formation observed in the dog under the influence of small doses of benzene. As pointed out by Simonds and Jones, the morphologic effects of benzene do not indicate that certain particular elements are concerned in the elaboration of antibodies to the exclusion of others, because the action is too general in that, while benzene affects the leukocytogenic centers and the leukocytes the most, it also acts, directly or indirectly, on the lymphocytes and the erythroblastic elements. The $\mathrm{x}$-ray, which also reduces the production of antibodies, does not permit any morphologic differentiation because it too is diffuse in its action, altho in a different order of intensity. Possibly the study of the action of substances closely related to benzene may yield results of interest with respect to these questions. The work of Milnikowa and Wersilowa ${ }^{23}$ on the action of phenylhydrazin ( and of hydroxylamin hydrochlorid) on the development of agglutinins for typhoid bacilli is limited to the demonstration that the effect in the doses used is one of restraint.

The results of the investigations into antibody-formation just cited indicate that the final elaboration of antibodies takes place outside the circulation, and the results of transfusion experiments by Carlson and myself point in the same direction. ${ }^{24}$ Assuming that such is the case, we have to consider the possibility that in benzenized rabbits the absorption and fixation of the antigen may be disturbed and delayed. Von Heinrich $^{25}$ explains the depressive action of the $x$-ray by assuming that it prevents the lymphatic apparatus from binding the antigen. We know that after the injection of considerable amounts, antigen may persist in the blood for some time, apparently even after the appearance of specific antibodies $;{ }^{20}$ hence the question arises whether the course of the antigen in the blood differs in the case of benzenized animals from that in normal animals. I have made some observations on this point which show that in rabbits injected intraperitoneally with 30 c.c. of sheep blood the blood serum may contain sheep protein in such form as to

${ }^{23}$ Centralbl. f. Bakteriol., I, O., 1912, 66, p. 520.

24 Jour. Infect. Dis., 1910, 7, p. 319.

is Centralbl. f. Bakteriol., I, O., 1913, 20, p. 421.

28 References hearing on this fact are cited by Zinsser, Arch. Int. Med., 1915, 16, p. 223. See also Gay and Rusk, Triv. Calif., Publ, in Pathol., 1912, 2, p. 59. 
be demonstrable by means of the precipitin test for from 10 to 12 days and sometimes longer, in one instance even on the 20th day, the test in this case being made with an antiserum of a titer of $1: 20000$ - that is, it would cause a precipitate in a dilution of sheep blood of $1: 20000$. I have not met any indications, however, that under the circumstances outlined, sheep protein is demonstrable by the precipitin method any longer in the blood of benzenized rabbits than in the blood of rabbits not injected with benzene, at least when antiserum of the titer of $1: 12000$, or thereabout, is used.

On account of its bearing on the question of what elements in the marrow and lymphatic tissues are concerned in the production of antibodies, the result of the following experiment may be of interest at this point:

In conjunction with Professor A. S. Loevenhart of the University of Wisconsin, I determined the production of lysin for sheep corpuscles in white rats which were kept in an atmosphere of $10 \%$ oxygen by means of the special apparatus devised by Professor Loevenhart to maintain atmospheres with controllable oxygen content. The rats under low oxygen pressure during the entire period of antibody-production developed an increase of hemoglobin and red cells of from 20 to $35 \%$ -total hemoglobin being increased $43 \%$ - as compared with that of the controls, but no demonstrable increase or decrease in the amount of lysin, as compared with that of controls. Hence, increase in red corpuscles under these conditions does not seem to be associated with changes in the production of antibodies as might be expected in view of the stimulating effect that acute anemia is known to have on this production; but of course without corroborative evidence this result alone, altho suggestive, does not permit one to exclude the erythrocytogenic centers from consideration as possible producers of antibodies.

The ultimate mechanism of the action of benzene, not only in restraining the production of antibodies, but in causing injury of a selective nature to marrow and lymphatic cells and leukocytes, invites further study.

\section{SUM MARY}

In rabbits the repeated injection of benzene in doses of 1 c.c. per kilo of rabbit weight at about the same time that sheep blood is injected greatly reduces the production of specific precipitin and lysin.

In considerably larger doses benzene has a like effect on the production of lysin in white rats. 
The reduction of antibody-formation under these circumstances is associated with grave lesions in the marrow, with leukopenia, and other changes characteristic of benzene intoxication, the leukocytes in the rabbit being of reduced phagocytic power.

In the dog, benzene ( 0.02 c.c. per kilo) may cause leukocytosis associated with increase in production of lysin for goat corpuscles.

So far as can be determined by the precipitin method, the course of the antigen in the blood appears the same in benzenized as in nonbenzenized rabbits.

At the height of antibody-production the injection of benzene appears to have but little effect on the leukocytes of the blood and on its antibody content, the precipitin especially persisting longer and with more fluctuation than otherwise.

Benzene may lower the resistance to infection by reduction (1) of antibody-production, (2) of the number of leukocytes, and (3) of leukocytic activity.

That benzene acts on elements that elaborate antibodies and that the leukocytogenic centers are concerned in this elaboration is indicated (a) in the rabbit, by the reduction of antibodies and of leukocytes and by the resistance to these effects when antibody-production is at or near its highest activity as measured by the concentration of antibodies in the blood, and (b) in the dog, when suitable doses are given, by leukocytosis and increased formation of lysin. 